\title{
ANALISIS SOAL DALAM BUKU SISWA MATEMATIKA KURIKULUM 2013 KELAS VIII SEMESTER I BERDASARKAN DIMENSI KOGNITIF DARI TIMSS
}

\author{
Budi Cahyono", Nurul Adilah ${ }^{2}$ \\ ${ }^{1,2}$ Jurusan Pendidikan Matematika FST UIN Walisongo Semarang \\ Jl. Walisongo No. 3-5 Semarang
}

\begin{abstract}
This study aimed to analyze the student math book of curriculum 2013 for first semester grades VIII issue Kemendikbud based on the cognitive dimension of the TIMSS. This report result based on the TIMSS that mathematical ability learners Indonesia is low, so that the government must assess the previous curriculum and impelementation curriculum of 2013. The method use a descriptive qualitative research. The subject is a matter of training and competence test questions each chapter in the book student math. The collection of data uses documentation. Guidelines for the analysis of matter based on the cognitive dimension of assessment framework of the TIMSS 2015. The results showes that 36 matter only reached the level of cognitive domain knowing with the percentage of $16.98 \%, 114$ matter has reach the level of applying with the percentage of $53.77 \%$, and 62 matter has reach the level of reasoning with the percentage of $29.25 \%$.
\end{abstract}

Keywords: Problem analysis; Students books; Cognitive dimension; TIMSS.

\section{PENDAHULUAN}

Pada abad 21 sekarang ini, tidak bisa dipungkiri bahwa seluruh kehidupan manus ia sudah mempergunakan matematika mulai dari perhitungan yang sederhana sampai menggunakan matematika yang lebih rumit. Banyak ahli menyatakan bahwa "mathematics is the queen as well as servant of all science" (matematika adalah ratu sekaligus pelayan semua ilmu pengetahuan). Ungkapan tersebut jelas menggambarkan bahwa ilmu matematika menduduki posisi nentral dalam kancah dunia ilmu pengetahuan karena seluruh cabang ilmu pengetahuan menggunakan ilmu matematika baik dalam skala teori maupun dalam implementasi kehidupan sehari-hari.

Peranan matematika dalam kehidupan pernah dilontarkan oleh Phytagoras. Dia menyatakan bahwa "angka-angka mengatur segalanya". Satu abad setelah kelahiran Nabi Muhammad SAW, Galileo Galilei (dalam Sampayya, 2007) menyatakan bahwa matematika adalah bahasa yang digunakan Tuhan dalam menulis alam semesta. Mereka menemukan bahwa ada satu aturan atau persamaan matematika dalam segala hal yang 
telah diciptakan Allah sebagai bahasa universal di alam semesta (Sampayya, 2007). Dalam Al-Qur'an juga disebutkan bahwa segala sesuatu diciptakan secara matematis. Hal ini sesuai firman Allah SWT dalam Q.S. al-Qamar/54: 49.

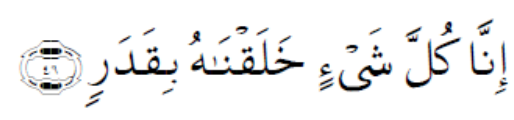

"Sesungguhnya Kami menciptakan segala sesuatu menurut ukuran"

Ayat di atas juga menunjukkan bahwa segala sesuatu diciptakan oleh Allah menurut ukurannya masing-masing dan semua jenis ukuran ditetapkan melalui perhitunganperhitungan (Sampayya, 2007). Semua bentuk perhitungan tersebut menghasilkan suatu ukuran yang digambarkan dalam angka. Segala ketentuan-ketentuan yang berlaku dalam angka di hamparan semesta raya merupakan bagian dari master plan penciptaan-Nya dalam hitungan matematis yang teramat tinggi. Jadi untuk memahami alam semesta ini, manusia harus mampu menguasai matematika dengan cara mempelajarinya. Oleh karena itu mengingat begitu pentingnya peran matematika dalam kehidupan, dalam pembelajaran di sekolah sangat diharapkan juga bagi peserta didik untuk menguasai dan mempelajari matematika karena matematika merupakan sarana berpikir ilmiah yang sangat diperlukan peserta didik. Selain itu, matematika juga dipakai sebagai alat ukur untuk menentukan kemajuan pendidikan di suatu negara sehingga beberapa studi internasional secara berkala mengukur dan membandingkan kemajuan pendidikan matematika di berbagai negara, maka negara perlu mengadakan evaluasi untuk mengetahui sejauh mana tingkat keberhasilan pendidikan yang telah dilaksanakan.

Salah satu studi internasional yang diikuti Indonesia untuk melihat prestasi hasil belajar matematika dan sains peserta didik kelas VIII jenjang Sekolah Menengah Pertama (SMP) adalah TIMSS (Trends in International Mathematics and Science Study). Soalsoal matematika dalam studi TIMSS mengukur tingkatan kemampuan siswa dari sekedar mengetahui fakta, prosedur atau konsep hingga menggunakannya untuk memecahkan masalah yang sederhana sampai masalah yang memerlukan penalaran tinggi (Wardhani \& Rumiati, 2011).

Hasil TIMSS tahun 2011 menunjukkan bahwa prestasi matematika siswa Indonesia berada di peringkat 38 dari 42 negara peserta. Indonesia hanya mampu meraih skor ratarata 386 poin dari rata-rata skor Internasional yang mencapai 500 poin. Skor rata-rata siswa Indonesia tertinggal jauh dari negara-negara tetangga, seperti Singapura, Malaysia, 
dan Thailand yang masing-masing mendapatkan skor 611, 440, dan 427 (Mullis, Martin, Foy, \& Arora, 2012). Hasil ini tidak jauh berbeda dari hasil keikutsertaan Indonesia dalam TIMSS pada tahun-tahun sebelumnya. Pada tahun 1999 Indonesia hanya menduduki peringkat 34 dari 38 negara. Skor rata-rata yang diperoleh adalah 403 sementara skor ratarata internasional adalah 487. Selanjutnya pada tahun 2003 Indonesia menduduki peringkat 35 dari 46 negara dengan skor rata-rata yang diperoleh adalah 411, sementara skor rata-rata internasional adalah 467 dan pada tahun 2007 siswa Indonesia menduduki peringkat 36 dari 49 negara dengan skor rata-rata yang diperoleh adalah 397, sementara skor rata-rata internasional adalah 500 .

Perolehan TIMSS yang rendah ini mengambarkan bahwa peserta didik Indonesia belum terbiasa menghadapi soal-soal yang membutuhkan kemampuan berpikir tingkat tinggi. Misalnya soal kontekstual, menuntut penalaran, argumentasi dankreativitas dalam menyelesaikannya.. Hasil dari survei TIMSS tersebut juga merujuk pada suatu kesimpulan bahwa prestasi peserta didik Indonesia tertinggal dan terbelakang.

Upaya pemerintah untuk memperbaiki ketertinggalan tersebut salah satunya dengan meluncurkan kurikulum baru pada tahun 2013, yaitu kurikulum 2013. Salah satu perbedaan antara implementasi kurikulum 2013 dan kurikulum sebelumnya adalah adanya buku siswa yang telah disediakan pemerintah sebagai buku teks wajib sumber belajar di sekolah bagi siswa (Kemendikbud, 2014).

Perbedaan kualitas buku teks pelajaran yang digunakan akan memberi pengaruh yang berbeda terhadap kemampuan siswa. Keberadaan buku teks sangat penting karena buku teks merupakan salah satu perangkat dasar dalam proses pembelajaran. Berdasarkan Peraturan Pemerintah No. 32 Tahun 2013 tentang standar nasional pendidikan, buku teks pelajaran adalah sumber pembelajaran utama untuk mencapai kompetensi yang telah ditetapkan. Buku teks juga berisi soal-soal yang digunakan sebagai alat ukur kemampuan siswa. Soal-soal itu digunakan untuk melatih tingkat kognitif siswa. Soal-soal yang terdapat dalam buku teks juga diharapkam mendorong dan mengukur domain kognitif sebagaimana karakteristik soal TIMSS. Hal tersebut untuk menganalisis apakah penerapan kurikulum 2013 dapat meningkatkan kemampuan matematika peserta didik Indonesia yang berada pada kategori rendah (Kunandar, 2014).

Menurut Cai, dkk., Li, dkk., dan Fan, sebagaimana dikutip oleh Delill (2006) menunjukkan bahwa penelitian tentang analisis buku lebih fokus pada isi. Hanya sedikit 
penelitian tentang analisis buku yang terfokus pada kualitas soal. Kenyataan lain menunjukkan bahwa masih banyak guru yang bergantung penuh pada buku teks sehingga satu-satunya sumber dalam pembelajaran adalah buku teks tersebut. Menurut Pepin (2015), sebagian besar guru lebih sering menyandarkan proses pembelajaran sehariharinya pada penggunaan buku teks, memutuskan apa yang harus diajarkan, bagaimana untuk mengajarkannya dan menyusun soal-soal serta latihan-latihan untuk siswa mereka berdasarkan buku teks yang mereka pilih sekalipun sumber belajar selain buku teks sangat banyak.

Begitu penting dan strategisnya posisi dan peran buku teks dalam meningkatkan mutu pendidikan terutama dalam prestasi matematika maka perlu diadakan sebuah penelitian tentang analisis atau kajian terhadap buku teks pelajaran matematika, khususnya pada implementasi tingkat kognitif yang terdapat butir-butir soal dalam buku teks matematika yang berjudul "Analisis Soal dalam Buku Siswa Matematika Kurikulum 2013 Kelas VIII Semester I Terbitan Kemendikbud Berdasarkan Dimensi Kognitif dari Trends in International Mathematics and Science Study (TIMSS)".

\section{METODE PENELITIAN}

Penelitian ini adalah penelitian deskriptif kualitatif, yaitu mengkaji soal-soal uji kompetensi pada buku matematika. Objek penelitian adalah soal latihan dan soal uji kompetensi tiap bab dalam buku siswa matematika kurikulum 2013 untuk kelas VIII semester I terbitan Kementerian Pendidikan dan Kebudayaan. Pengumpulan data yang dilakukan menggunakan metode dokumentasi. Pedoman analisis soal berdasarkan dimensi kognitif dari assessment framework TIMSS 2015 yang intinya terletak pada kekuatan penalaran matematis siswa serta kemampuan menerapkannya dalam kehidupan sehari-hari. Selanjutnya analisis dilakukan dengan mendeskripsikan dan mengelompokkan tiap soal berdasarkan domain kognitif assessment framework TIMSS 2015 yakni knowing (pengetahuan), applying (penerapan) dan reasoning (penalaran).

Kriteria aspek kognitif dari domain kognitif assessment framework TIMSS 2015 knowing (pengetahuan) adalah recall (mengingat), recognize (mengenali), compute (menghitung), retrieve (mengambil), classify/order (mengklasifikasikan), dan measure (mengukur). Kriteria aspek kognitif dari domain kognitif applying (penerapan) adalah 
determine (menentukan), represent/model (merepresentasikan/memodelkan), dan implementation (mengimplementasikan). Kriteria aspek kognitif dari domain kognitif reasoning (penalaran) adalah analyze (menganalisis), integrated/synthesize (menyatukan/mensistesis), evaluate (mengevaluasi), draw Conclusions (mengambil kesimpulan), generalize (menggeneralisasikan), dan justify (menjustifikasi).

Adapun soal-soal uji kompetensi dikaji berdasarkan tingkatan kognitif menurut Mullis, Martin, Ruddock, O’Sullivan, \& Preuschoff (2009) yaitu pengetahuan (knowing), penerapan (applying), dan penalaran (reasoning). Setelah dilakukan pendeskripsian, selanjutnya dilakukan pengelompokan, kemudian dianalisis sesuai ranah kognitif, dan yang terakhir divalidasi oleh ahli. Hasilnya diperoleh persentase dari setiap domain kognitif, yakni pengetahuan (knowing), penerapan (applying), dan penalaran (reasoning) pada buku.

\section{HASIL PENELITIAN DAN PEMBAHASAN}

Penelitian ini berhasil mengumpulkan data deskriptif mengenai banyak soal yang sesuai dengan dimensi kognitif dari assessment framework TIMSS 2015. Analis is dalam penelitian ini dilakukan terhadap 212 dari 215 jumlah total soal secara keseluruhan yang terdiri dari soal latihan dan soal uji kompetensi pada tiap bab dalam buku siswa matematika kurikulum 2013 kelas VIII semester I. Adapun 3 soal lainnya tidak dianalis is berdasarkan dimensi kognitif dari TIMSS karena soal-soal tersebut merupakan soal yang kurang valid atau salah penyajian soal, sehingga soal-soal tersebut tidak mengandung domain kognitif. Berdasarkan hasil analisis terhadap tingkatan domain dan aspek kognitif yang termuat dalam soal-soal latihan dan soal uji kompetensi pada buku pelajaran matematika yang menjadi subjek penelitian, maka diperoleh data sebagaimana pada Tabel 1 dan Gambar 1: 
Tabel 1.

Distribusi Jumlah Soal dan Persentase dalam Domain Kognitif Setiap Bab

\begin{tabular}{ccccccccc}
\hline No. & BAB & \multicolumn{9}{c}{ BANYAK DOMAIN KOGNITIF } & \multirow{2}{*}{\begin{tabular}{c} 
Jumlah Soal \\
\cline { 3 - 7 }
\end{tabular}} & & $\begin{array}{c}\text { Jumlah } \\
\text { Soal }\end{array}$ & $\%$ & $\begin{array}{c}\text { Jumlah } \\
\text { Soal }\end{array}$ & $\%$ & Jumlah & $\%$ & Setiap Bab \\
& & A & & Soal & & \\
\hline 1 & I & 8 & $20.51 \%$ & 21 & $53.85 \%$ & 10 & $25.64 \%$ & 39 \\
2 & II & 23 & $34.33 \%$ & 29 & $43.28 \%$ & 15 & $22.39 \%$ & 67 \\
3 & III & 3 & $14.29 \%$ & 15 & $71.43 \%$ & 3 & $14.29 \%$ & 21 \\
4 & IV & 1 & $2.50 \%$ & 28 & $70.00 \%$ & 11 & $27.50 \%$ & 40 \\
5 & V & 0 & $0.00 \%$ & 12 & $38.71 \%$ & 19 & $61.29 \%$ & 31 \\
6 & VI & 1 & $7.14 \%$ & 9 & $64.29 \%$ & 4 & $28.57 \%$ & 14 \\
\hline \multicolumn{2}{c}{ Jumlah } & 36 & $16.98 \%$ & 114 & $53.77 \%$ & 62 & $29.25 \%$ & 212 \\
\hline
\end{tabular}

Keterangan: $\mathrm{A}=$ Knowing; $\mathrm{B}=$ Applying; $\mathrm{C}=$ Reasoning

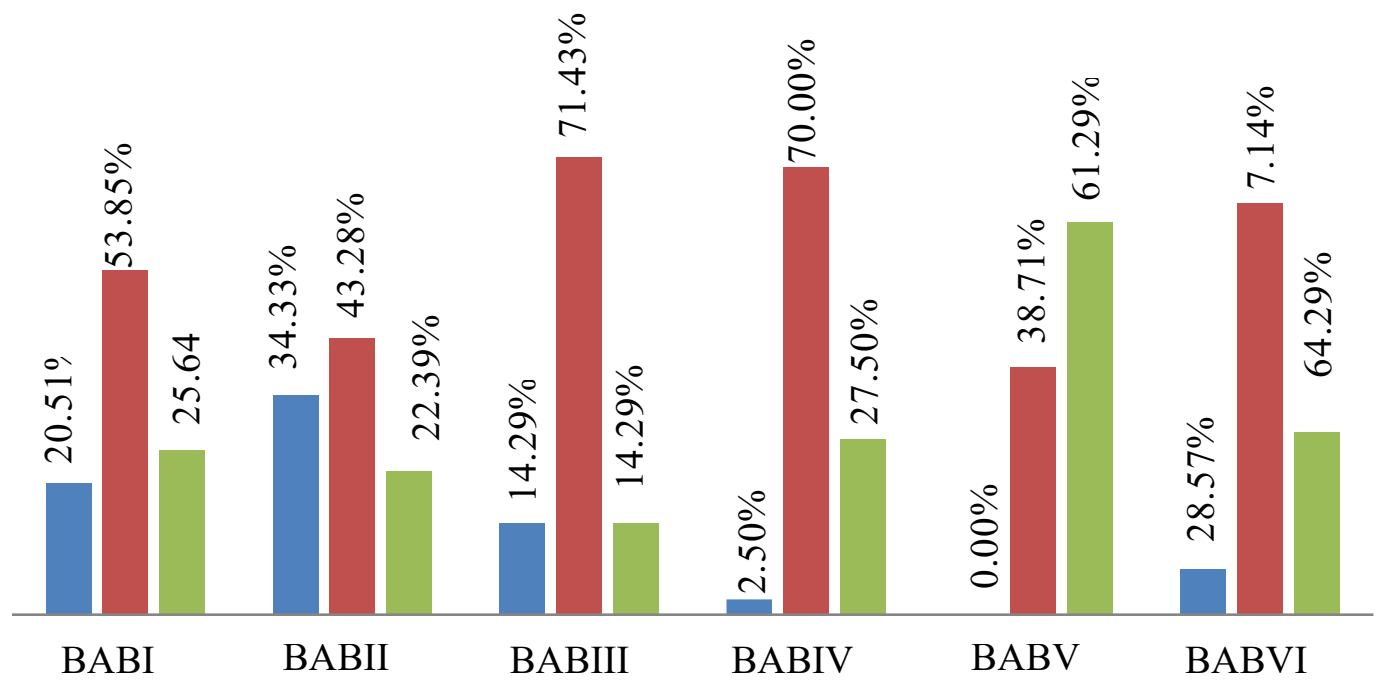

$\square$ Knowing $\square$ Applying $\square$ Reasoning

\section{Gambar 1.}

Persentase Domain Kognitif Setiap Bab dalam Buku Matematika Siswa

Berdasarkan Tabel 1 dan Gambar 1, soal-soal yang ada hanya mencapai tingkat kognitif pada domain knowing dengan persentase tertinggi terdapat di bab II dengan persentase $34,33 \%$. Soal-soal yang mencapai tingkat kognitif pada domain applying dengan persentase tertinggi terdapat di bab III dengan persentase sekitar 71,43\%. Sedangkan soal-soal yang telah mencapai tingkat kognitif pada domain reasoning dengan persentase tertinggi terdapat di bab V dengan persentase $61,29 \%$. Soal-soal yang disajikan pada bab I, II, III, IV dan VI sudah mencakup semua domain kognitif menurut assessment framework TIMSS 2015. Akan tetapi, pada bab V tidak ditemukan soal yang hanya 
mencapai tingkat knowing. Keseluruhan soal pada bab V sudah mencapai tingkat kognitif applying dan reasoning.

Soal-soal dalam buku siswa matematika kurikulum 2013 kelas VIII semester I terbitan Kemendikbud sebagian besar merupakan soal-soal applying. Artinya soal-soal yang ada bersifat penerapan yang mendorong siswa untuk menyelesaikan masalah rutin. Hal ini dapat dilihat dari persentase domain applying yang selalu tertinggi di setiap bab, kecuali pada Bab V karena domain yang mendapat persentase tertinggi pada Bab V adalah domain kognitif reasoning.

Secara keseluruhan, berdasarkan hasil analisis terhadap muatan domain kognitif pada soal-soal latihan dan soal uji kompetensi tiap bab pada buku siswa matematika kurikulum 2013 kelas VIII semester I terbitan Kemendikbud, maka diperoleh data yang disajikan pada Tabel 2:

\section{Tabel 2}

Jumlah dan Persentase Domain Kognitif Dalam Buku

\begin{tabular}{cccc}
\hline Buku Matematika Kelas VIII & \multicolumn{3}{c}{ Domain Kognitif } \\
\cline { 2 - 4 } Kurikulum 2013 & Knowing & Applying & Reasoning \\
\hline Jumlah & 36 & 114 & 62 \\
Persentase & $16.98 \%$ & $53.77 \%$ & $29.25 \%$ \\
\hline
\end{tabular}

Persentase setiap domain kognitif yang tercapai dalam soal pada buku siswa matematika kurikulum 2013 kelas VIII semester I terbitan Kemendikbud disajikan pada Gambar 2.

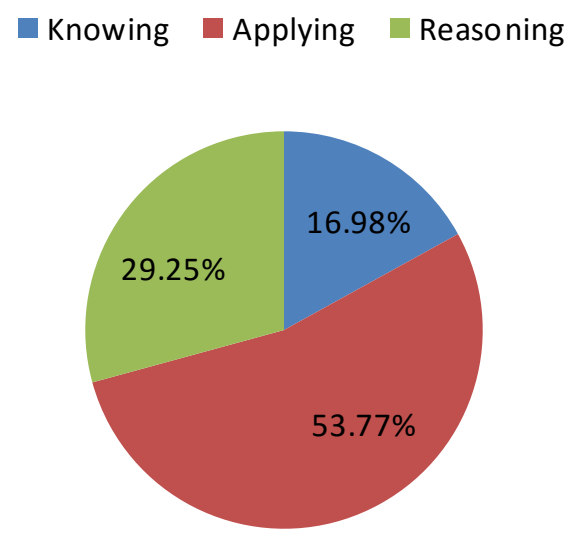

Gambar 2.

Persentase Domain Kognitif Pada Buku Matematika Kelas VIII Kurikulum 2013 
Dalam buku siswa matematika kurikulum 2013 kelas VIII semester I, diperoleh 36 soal hanya mencapai tingkat kognitif pada domain knowing dengan persentase $16,98 \%$, 114 soal sudah mencapai tingkat kognitif pada domain applying dengan persentase $53,77 \%$ dan 62 soal sudah mencapai tingkat kognitif pada domain reasoning dengan persentase 29,25\%. Jadi, soal-soal dalam buku siswa matematika kurikulum 2013 kelas VIII semester I sebagian besar merupakan soal yang telah mencapai tingkat kognitif pada domain applying yaitu soal-soal yang bersifat penerapan yang mendorong peserta didik untuk menyelesaikan masalah rutin. Adapun data terkait kandungan aspek kognitif pada masing-masing domain kognitif disajikan dalam Tabel 3.

Tabel 3.

Jumlah dan Proporsi Aspek Kognitif Pada Masing-Masing Domain Dalam Buku

\begin{tabular}{|c|c|c|c|c|c|c|c|c|c|}
\hline \multirow{2}{*}{$\begin{array}{l}\text { Domain } \\
\text { Kognitif }\end{array}$} & \multirow[t]{2}{*}{ Aspek Kognitif } & \multicolumn{6}{|c|}{$\mathrm{BAB}$} & \multirow[t]{2}{*}{ Jumlah } & \multirow{2}{*}{$\begin{array}{c}\text { Persentase } \\
\%\end{array}$} \\
\hline & & $\mathrm{I}$ & II & III & IV & $\mathrm{V}$ & VI & & \\
\hline \multirow{7}{*}{ 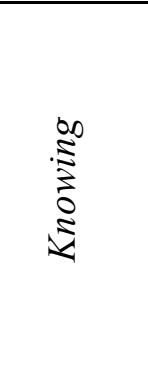 } & Recall & 6 & 19 & 3 & 1 & 0 & 0 & 29 & $33,72 \%$ \\
\hline & Recognize & 2 & 4 & 0 & 0 & 0 & 0 & 6 & $6,98 \%$ \\
\hline & Compute & 0 & 19 & 1 & 0 & 0 & 0 & 20 & $23,26 \%$ \\
\hline & Retrieve & 8 & 0 & 1 & 0 & 0 & 1 & 10 & $11,63 \%$ \\
\hline & Classify/order & 7 & 14 & 0 & 0 & 0 & 0 & 21 & $24,42 \%$ \\
\hline & Measure & 0 & 0 & 0 & 0 & 0 & 0 & 1 & $0,00 \%$ \\
\hline & Jumlah & 23 & 56 & 5 & 1 & 1 & 0 & 86 & $100,00 \%$ \\
\hline \multirow{5}{*}{ 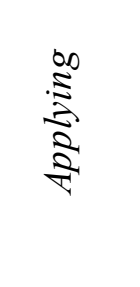 } & Determine & 18 & 15 & 9 & 14 & 2 & 9 & 66 & $38,29 \%$ \\
\hline & Represent/model & 18 & 8 & 7 & 7 & 0 & 9 & 49 & $28,00 \%$ \\
\hline & Implement & 1 & 17 & 6 & 23 & 12 & 0 & 59 & $33,71 \%$ \\
\hline & Jumlah & 37 & 40 & 22 & 43 & 14 & 18 & 174 & $100,00 \%$ \\
\hline & Analyze & 6 & 8 & 1 & 7 & 12 & 0 & 34 & $36,56 \%$ \\
\hline \multirow{6}{*}{ 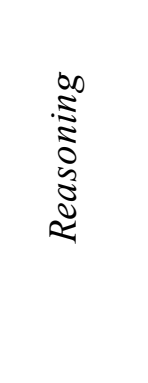 } & $\begin{array}{l}\text { Integrated } \\
\text { synthesize }\end{array}$ & 3 & 7 & 1 & 8 & 4 & 0 & 23 & $24,73 \%$ \\
\hline & Evaluate & 0 & 3 & 1 & 2 & 5 & 0 & 11 & $11,83 \%$ \\
\hline & Draw conclusions & 0 & 0 & 1 & 0 & 0 & 4 & 5 & $5,38 \%$ \\
\hline & Generalize & 0 & 0 & 0 & 2 & 0 & 0 & 2 & $2,15 \%$ \\
\hline & Justify & 5 & 4 & 1 & 2 & 6 & 0 & 18 & $19,35 \%$ \\
\hline & Jumlah & 14 & 22 & 5 & 21 & 27 & 4 & 93 & $100,00 \%$ \\
\hline
\end{tabular}

Berdasarkan Tabel 3, diketahui bahwa soal-soal pada domain knowing, aspek kognitif yang lebih banyak termuat adalah recall yaitu sebanyak 33,72\%, classify/order $24,42 \%$, compute $23,26 \%$, retrieve $11,63 \%$ dan recognize $6,98 \%$. Adapun measure tidak 
termuat dalam soal pada domain knowing. Untuk soal-soal pada domain applying, aspek kognitif yang lebih banyak termuat yaitu determine 38,29\%, implement sekitar 33,71\% dan represent/model sekitar 28,00\%. Adapun untuk soal-soal pada domain reasoning, aspek kognitif yang lebih banyak termuat adalah analyze sekitar 36,56\%, integrated/synthesize 24,73\%, justify 19,35\%, evaluate 11,83\%, draw conclusions 5,38 $\%$ dan yang paling sedikit generalize yaitu sekitar 2,15\%. Adapun contoh soal yang berada pada tingkat kognitif pada domain knowing dalam buku adalah soal latihan 2.2 nomor. 1 yaitu:

$$
(13 a-8 b)+(12 a+9 b)=\ldots
$$

Soal di atas dikategorikan pada domain knowing karena memuat aspek kognitif recall dengan indikator "mengingat operasi penjumlahan bentuk aljabar dan mengingat notasi matematika". Selain itu, juga memuat aspek kognitif compute dengan indikator "menyelesaikan prosedur algoritmik" dan memuat indikator classify/order dengan indikator "mengelompokkan suku-suku yang sejenis". Adapun contoh soal yang berada pada tingkat kognitif pada domain applying dalam buku adalah soal latihan 6.3 nomor. 1, yaitu:

Buatlah diagram lingkaran dari data banyak siswa kelas VIII berikut ini:

\begin{tabular}{ccccccc}
\hline \multirow{2}{*}{$\begin{array}{c}\text { Jenis } \\
\text { Kelamin }\end{array}$} & \multicolumn{7}{c}{ Banyak Siswa } \\
\cline { 2 - 7 } & Kelas & Kelas & Kelas & Kelas & Kelas & Kelas \\
& VIII-A & VIII-B & VIII-C & VIII-D & VIII-E & VIII-F \\
\hline Laki-laki & 12 & 14 & 13 & 15 & 16 & 14 \\
Perempuan & 18 & 17 & 18 & 18 & 16 & 18 \\
\hline
\end{tabular}

Soal di atas dikategorikan pada domain applying karena memuat aspek kognitif represent/model dengan indikator "menyajikan data dalam bentuk diagram, tabel atau grafik", dan memuat aspek kognitif determine karena memuat indikator "menentukan alat bantu yang tepat dalam membuat diagram". Adapun contoh soal yang berada pada tingkat kognitif pada domain applying dalam buku adalah soal latihan 6.3 nomor 1 yaitu:

Suatu ketika Jodi dan Nikolas diminta menentukan apakah $8-17-15$ adalah suatu Tripel Phytagoras, kemudian mereka menjawab. 

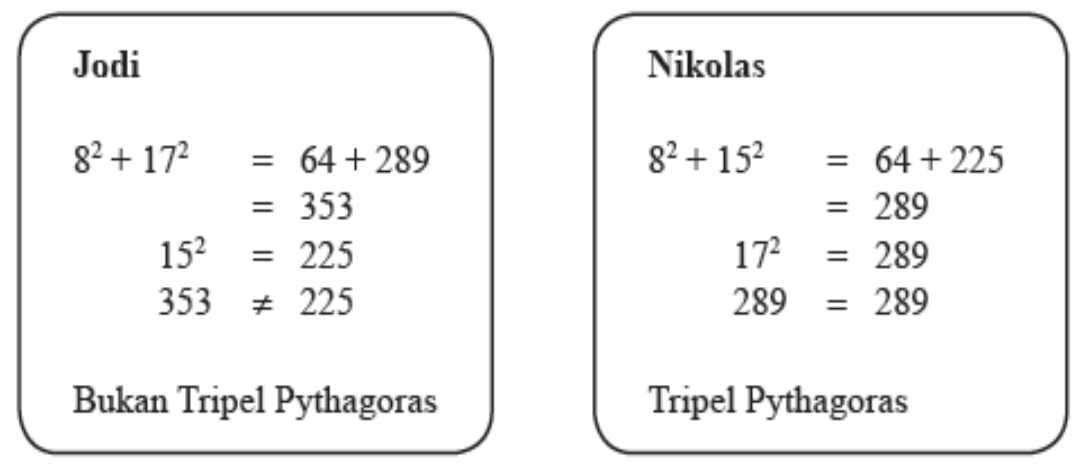

Manakah yang benar? Jelaskan!

Soal di atas memuat aspek kognitif evaluate karena memuat indikator, "mengevaluasi strategi dan solusi alternatif untuk menyelesaikan masalah", dan memuat aspek kognitif justify karena memuat indicator, "memberikan argumen matematis yang mendukung strategi/solusi”. Soal di atas termasuk dalam tingkatan soal reasoning.

Mengacu assessment framework TIMSS 2015, proporsi kemampuan yang diuji pada dimensi kognitif untuk kelas VIII SMP mencapai 35\% untuk knowing (pengetahuan), 45\% untuk applying (penerapan) dan 25\% untuk reasoning (penalaran). Hal ini dapat disimpulkan bahwa buku siswa matematika kurikulum 2013 untuk kelas VIII semester I cakupan domain kognitifnya belum sesuai proporsi yang diuji pada dimensi kognitif dalam TIMSS. Sementara itu untuk domain applying dan reasoning justru melebihi proporsi yang diuji dalam TIMSS, sedangkan domain knowing lebih sedikit dari proporsi yang diuji dalam TIMSS. Akan tetapi, soal-soal dalam buku siswa matematika kurikulum 2013 untuk kelas VIII semester I ini sudah memberikan bekal untuk melatih dan mendorong tingkat perkembangan berpikir peserta didik. Hal ini dapat dilihat dari persentase domain applying dan reasoning yang lebih tinggi dari persentase domain knowing pada soal. Soal pada tingkat applying lebih ditekankan dalam buku ini, karena untuk menyelesaikan soal pada tingkat applying peserta didik perlu untuk menerapkan pengetahuan matematika yang meliputi konsep, fakta, prosedur dan pemahaman konsep matematika untuk menghasilkan kemampuan representasi. Sebab ide-ide dalam kemampuan representasi ini merupakan inti dalam kemampuan berpikir dan komunikasi matematis, sedangkan untuk menyelesaikan soal pada tingkat reasoning peserta didik dituntut menggunakan logika dan kemampuan berpikir sistematis termasuk menggunakan penalaran intuitif dan penalaran induktif yang berdasar pada pola-pola 
yang dapat digunakan untuk memecahkan masalah baru dan non familiar.

Analisis tambahan dalam penelitian ini, adalah adanya kesalahan penyajian soal ataupun soal yang dinilai kurang valid. Soal-soal tersebut antara lain:

1. Soal nomor 4 latihan 3.1

4. Diketahui $K=\{p, q\}$ dan $L=\{2,3,4\}$

a. Buatlah semua pasangan berurutan dari himpunan $A$ ke himpunan $B$ yang membentuk fungsi

b. Tentukan banyaknya fungsi yang mungkin dari himpunan $A$ ke himpunan $B$.

Pada soal di atas, himpunan yang diketahui adalah himpunan $\mathrm{K}$ dan himpunan $\mathrm{L}$.

Namun, perintah/pertanyaan yang diajukan pada poin a dan $b$ menggunakan himpunan A dan himpunan B bukan himpunan $\mathrm{K}$ dan himpunan $\mathrm{L}$.

2. Soal nomor 2 uji kompetensi 4

2. Ketut dan Kadek menghitung kemiringan garis yang melalui titik $A(15,4)$ dan $B(-6,-13)$.

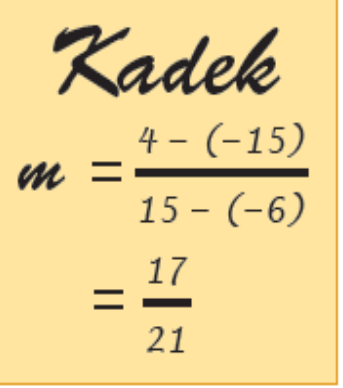

$$
\begin{aligned}
& \text { Ketut } \\
& m=\frac{4-13}{15-6} \\
& =\frac{9}{1}
\end{aligned}
$$

Terlihat bahwa soal diatas belum lengkap, karena tidak ada instruksi yang harus dilakukan. Seharusnya ada pernyataan "Perhitungan siapakah yang benar?"

3. Soal nomor 3 latihan 6.2

3. Data jenis pekerjaan siswa kelas VIII disajikan dalam tabel sebagai berikut.

\begin{tabular}{|l|l|c|}
\hline No & Jenis Pekerjaan & Banyak orang tua \\
\hline 1 & Pegawai Negeri & 35 \\
\hline 2 & Pegawai BUMN & 15 \\
\hline 3 & TNI/POLRI & 10 \\
\hline 4 & Pegawai swasta & 20 \\
\hline 5 & Pedagang & 25 \\
\hline 6 & Petani & 40 \\
\hline 7 & Lain-lain & 45 \\
\hline
\end{tabular}


Soal tersebut hanya diketahui sebuah data mengenai jenis pekerjaan orang tua siswa. Tidak ada perintah atau pertanyaan yang diajukan dalam soal, sehingga soal tersebut dikategorikan soal yang salah atau kurang valid.

Secara keseluruhan dari semua soal latihan dan soal uji kompetensi tiap bab yang terdapat pada buku siswa matematika kurikulum 2013 kelas VIII semester I terbitan Kemendikbud, terdapat 3 soal yang mempunyai kesalahan penyajian maupun soal yang dinilai salah atau kurang valid, sehingga soal tersebut tidak memuat domain maupun aspek kognitif.

\section{SIMPULAN DAN SARAN}

Berdasarkan hasil penelitian yang diperoleh, maka dapat disimpulkan bahwa dari 212 soal yang dianalisis, diperoleh 36 soal hanya mencapai tingkat kognitif pada domain knowing dengan persentase 16,98\%, 114 soal sudah mencapai tingkat kognitif pada domain applying dengan persentase 53,77\%, dan 62 soal sudah mencapai tingkat kognitif pada domain reasoning dengan persentase 29,25\%. Soal-soal pada domain knowing, aspek kognitif yang termuat adalah recall 33,72\%, classify/order $24,42 \%$, compute $23,26 \%$, retrieve $11,63 \%$ dan recognize $6,98 \%$. Untuk soal-soal pada domain applying, aspek kognitif yang termuat yaitu determine 38,29\%, implement 33,71\% dan represent/model $28,00 \%$. Adapun untuk soal-soal pada domain reasoning, aspek kognitif yang termuat adalah analyze 36,56\%, integrated/synthesize 24,73\%, justify 19,35\%, evaluate $11,83 \%$, draw conclusions $5,38 \%$ dan generalize $2,15 \%$.

Persentase domain kognitif yang termuat dalam soal-soal pada buku siswa, cakupan domain kognitifnya belum sesuai proporsi yang diuji pada dimensi kognitif dalam TIMSS. Akan tetapi, soal-soal dalam buku siswa matematika kurikulum 2013 ini sudah memberikan bekal untuk melatih dan mendorong tingkat perkembangan berpikir peserta didik. Di dalam soal-soal yang dianalisis juga masih terdapat soal-soal yang salah penyajian maupun kurang valid. Oleh karena itu, buku siswa matematika kurikulum 2013 kelas VIII semester I terbitan Kemendikbud bisa dijadikan pedoman dalam pembelajaran dilihat dari kelebihan penyajian soalnya dalam mencapai tingkat kognitif, meskipun masih perlu diadakan penyempurnaan dan perbaikan pada beberapa soal. 


\section{DAFTAR RUJUKAN}

Delill, H. (2006). An analysis of geometry problems in 6-8 grades Turkish mathematics textbooks. Skripsi tidak dipublikasikan. Turki: Middle East Technical University.

Hayat, B \& Suhendra, Y. (2011). Benchmark internasional mutu pendidikan. Jakarta: Bumi Aksara.

Kemendikbud. (2014). Matematika SMP/MTs Kelas VIII Semester 1. Jakarta: Kemendikbud.

Kunandar, (2014). Penilaian autentik (Penilaian hasil belajar peserta didik berdasarkan kurikulum 2013): Suatu pendekatan praktis. Jakarta: Rajawali Press.

Mullis, I. V. S., Martin, M. O., Ruddock, G. J., O’Sullivan, C. Y., \& Preuschoff, C. (2009, September). TIMSS 2011 assessment frameworks. Chesnut Hills, MA: Boston College.

Mullis, I. V. S., Martin, M. O., Foy, P., \& Arora, A. (2012). TIMSS 2011 international result in mathematics. Chesnut Hills, MA: Boston College.

Mulyasa, E. (2014). Pengembangan dan implementasi kurikulum 2013, Bandung: PT Remaja Rosdakarya.

Pepin, B. (2015, Maret 19). Mathematical tasks in textbooks: Developing an analytical tool based on connectivity. Diperoleh dari http://dg.icme11.org/document/get/245.

Sampayya, A. S. A. (2007). Keseimbangan matematika dalam al-Qur'an. Jakarta: Penerbit Republika.

Balitbang Kemdikbud. (2011). Survei internasional TIMSS. Diperoleh 4 Maret 2015, dari http://litbang.kemdikbud.go.id/index.php/survei-internasional-timss.

Wardhani, S \& Rumiati. (2011). Instrumen penilaian hasil belajar matematika SMP: Belajar dari PISA dan TIMSS. Yogyakarta: Pusat Pengembangan dan Pemberdayaan Pendidik dan Tenaga Kependidikan (PPPPTK) Matematika. 